\title{
A study on adoption of e-commerce practices among the Indian farmers with specific reference to North Gujarat region
}

\section{VIPUL B. PATEL, A.K. ASTHANA, KIRAN J. PATEL AND KUNDAN M. PATEL}

\begin{abstract}
Across the world, there is a continuation of the impressive growth of retail e-commerce. Since the e-commerce sector in country like India is rapidly growing, changes can be seen over a year. Many players from country as well as international economy have been attracted towards e-commerce business. In the year 2015, estimated size of retail e-commerce sales in the world is 994.5 US\$ billions while same in country like India is only 22 US\$ billions which reveals lesser contribution even having second largest populated economy in the world. In order to enhance the e-commerce market in the country, it is necessary to involve people from different sections of society. One of them is rural India especially farmers who transacts for millions of transactions in agricultural sector. Therefore, it is very imperative to study the factors influencing adoption of ecommerce practices by farmers in India. E-commerce jaints like Alibaba.com, Amazone, Flipkart, Snapdeal and other local players have started many practices which are useful and beneficial to Indian farmers. In this study, data was collected from 310 farmers of Mehsana and Banaskantha districts of north region of Gujarat State. Data was analyzed using multiple regression technique of data analysis. The results of the study revealed that perceived usefulness, perceived ease of use, self efficacy, trust and technical skill and resources highly influence attitude of farmers for adoption of e-commerce practices which in turn affect intension of farmers towards adoption of e-commerce practices. Among all, technical skill and available resources to farmers is prime concern to adoption.
\end{abstract}

KEY WORDS : Adoption, e-commerce practices, Intention, Trust, Technical skill, Resources

How to cite this paper : Patel, Vipul B., Asthana, A.K., Patel, Kiran J. and Patel, Kundan M. (2016). A study on adoption of e-commerce practices among the Indian farmers with specific reference to North Gujarat region. Internat. J. Com. \& Bus. Manage, 9(1) : 1-7.

\section{MEMBERS OF THE RESEARCH FORUM}

Correspondence to:

VIPUL B. PATEL, V.M. Patel College of Management Studies, Ganpat University, KHERVA (GUJARAT) INDIA

Email: vbp01@ganpatuniversity.ac.in

\section{Authors' affiliations:}

A.K. ASTHANA, Institute of Cooperative Management, BHOPAL (M.P.) INDIA

Email: dearasthana@gmail.com

KIRAN J. PATEL ANd KUNDAN M. PATEL, V. M. Patel College of Management Studies, Ganpat University, KHERVA (GUJARAT) INDIA 